\title{
The length-weight relationships and condition factor of an endemic Marosatherina ladigesi Ahl, 1936 in Walanae Cenranae River Watershed, South Sulawesi, Indonesia
}

\author{
Adiara Firdhita Alam Nasyrah ${ }^{1 *}$, Muhammad F. Rahardjo ${ }^{1}$, Charles P. H. Simanjuntak ${ }^{1}$, \\ Muhammad Nur $^{2}$ \\ ${ }^{1}$ Department of Aquatic Resources Management, Faculty of Fisheries and Marine Sciences, Bogor \\ Agricultural University, Indonesia \\ ${ }^{2}$ Department of Fisheries, Sulawesi Barat University, Indonesia
}

\begin{abstract}
Marosatherina ladigesi is an endemic fish species in South Sulawesi and is famous as ornamental fish. However, the biological information of this species is still restricted. This research direct analyzes the length-weight relationships and condition factors of $M$. ladigesi. Sampling was held monthly from May 2018 to April 2019 in the Walanae Cenranae River Watershed, South Sulawesi. Fish samples were assembled by seine net. A total of $550 \mathrm{M}$. ladigesi were collected consisted of 227 fish in Camba River, 88 fish in Sanrego River, and 235 fish in Batu Puteh River. The length-weight relationship of male and female fish was $\mathrm{W}=$ $0,0002 \mathrm{~L}^{2,74}$ and $\mathrm{W}=0,00004 \mathrm{~L}^{3,23}$ in Camba River, $\mathrm{W}=0,0001 \mathrm{~L}^{2,78}$ and $\mathrm{W}$ $=0,0001 \mathrm{~L}^{2,92}$ in Sanrego River, $\mathrm{W}=0,0001 \mathrm{~L}^{2,88}$ and $\mathrm{W}=0,00006 \mathrm{~L}^{3,12}$ in Batu Puteh River, respectively. In Camba and Batu Puteh Rivers, the growth pattern of male and female fish were negative allometric and positive allometric, respectively. Conversely, the growth patterns of male and female fish in the Sanrego River were isometric. The condition factor fish in Sanrego River was lower than Camba and Batu Puteh River. These findings are valuable data for establishing a monitoring and conservation of this endemic species in its habitat.
\end{abstract}

\section{Introduction}

That one of the biodiversity hotspots is Sulawesi Island, which resides between the Sunda and Sahul shelves well known in the Wallacea region. This can be referred from several endemic fishes in Sulawesi's freshwater environment. Sulawesi has endemic freshwater fish species that have been described by several researchers, namely 23 species [1], 52 species [2], 57 species [3], 65 species [4], 68 species [5]. The quantity of endemic fish species continues to increase with the finding of new endemic freshwater fish. Some of them are Oryzias dopingdopingensis [6], Nomorhamphus versicolor [7], Nomorhamphus aenigma [8], and Schismatogobius limmoni n. sp [9]. Currently, there are 72 species of endemic

\footnotetext{
${ }^{*}$ Corresponding author: firdhitaadiara@gmail.com
} 
freshwater fish in Sulawesi from four orders and seven families. Marosatherina ladigesi is known as the endemic fish of South Sulawesi.

The diversity of fish species in Sulawesi is dominated by lake species, which are ancient lakes in the world. Different things can be seen from the species in the Sulawesi rivers, which are currently less desirable with a limited number of studies. Marosatherina ladigesi is endemic fish that only belongs to the family Telmatherinidae, which is inhabited in the river. At present, anthropogenic activities, including destructive fishing and habitat degradation caused by the dredging of sand, have continued to threaten the ecological functions of these wetlands $[10,11]$. It carried $M$. ladigesi to the red list of threatened IUCN, the category of vulnerable species. To maintain this species in its habitat, the conservation efforts of this fish species must be carried out immediately.

Research related to $M$. ladigesi is interesting that many studies in these fish have been carried out, such as phylogenetic [12], bio ecology, morphology, and karyotypes [10], genetic variation [13], reproductive biology $[14,15,16,17,18]$, reproduction and growth in ex situ habitats [19], the effect of feed treatment on growth [20], scientific study of Sulawesi rainbow fish [21], domestication [22, 23], development of embryos and larvae on a laboratory scale [24]. In addition, basic biological information has never been disclosed.

The length-weight relationship (LWR) and condition factor (K) have limited information, even though LWR and $\mathrm{K}$ are also pivotal in fisheries management for comparative growth studies. LWR and K of this species have only been reported by [25], but it was in Maros District, including Bantimurung and Pattunuang Rivers, and does not cover all seasons. This research direct analyzes LWR and condition factors of M. ladigesi in Walanae Cenranae Watershed river. The result of this study will be helpful for Celebes rainbow fish conservation.

\section{Materials and Methods}

The research was held monthly from May 2018 to April 2019 in some Walanae Cenranae River Watershed, South Sulawesi. Fish sampling was done in three rivers, including Camba

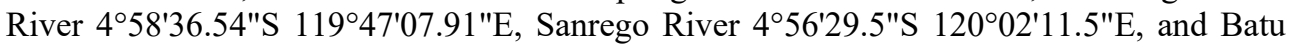
Puteh River 445'40.6"S 11959'45.1" E (Fig. 1).

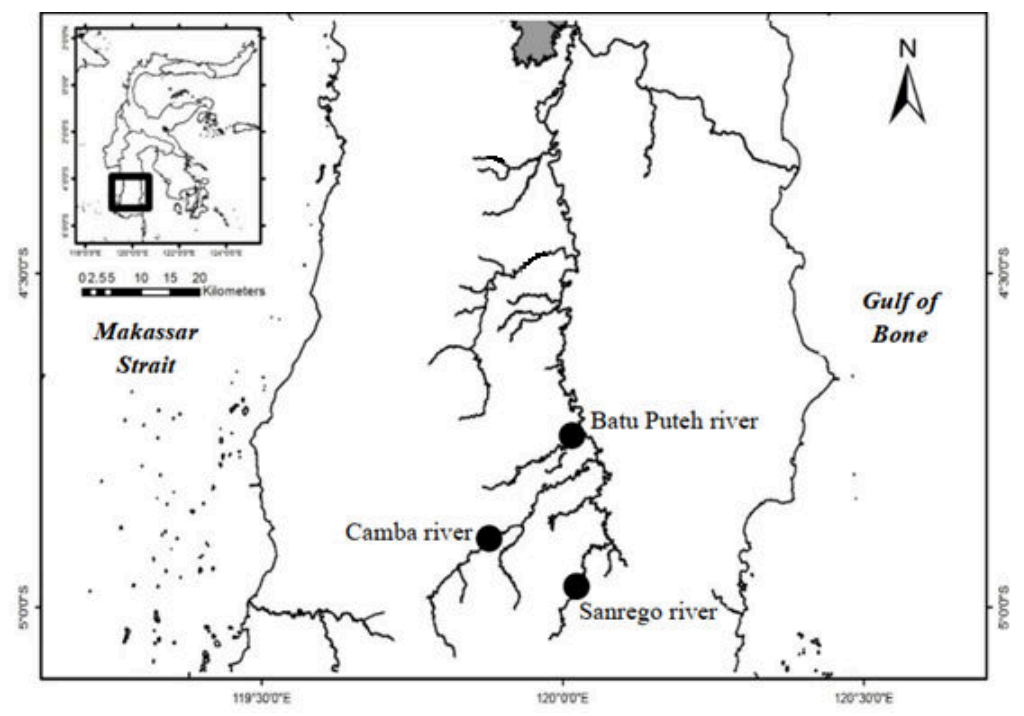

Fig. 1. Location of the sampling sites of Marosatherina ladigesi 
Fish samples were assembled with a seine net $(5 \mathrm{~m}$ long, $2 \mathrm{~m}$ wide, and $1 \mathrm{~mm}$ mesh size). The selection of fish samples was made by taking all the catches. Fishes were preserved in formalin with a concentration of $10 \%$ for $2-3$ hours. After that, fish samples were washed with clean water and stored in $80 \%$ ethanol. In the laboratory, specimens were measured for total length (digital caliper; $0.1 \mathrm{~mm}$ accuracy) and body weight (digital scale; $0.0001 \mathrm{~g}$ accuracy). The fish samples were dissected for sex and gonad development stage identification. The gonad development stage was determined and classified based on macroscopic characteristics of the gonad maturity modified by [10] in Table 1 :

Table 1. Classification of gonad maturity stage $M$. ladigesi

\begin{tabular}{|c|c|c|}
\hline Stage & Male & Female \\
\hline $\begin{array}{c}\mathrm{I} \\
\text { (Immature) }\end{array}$ & $\begin{array}{l}\text { Testes are shaped like a thread, } \\
\text { and the surface color is like } \\
\text { milky. }\end{array}$ & $\begin{array}{l}\text { Ovary shaped like a thread, gray } \\
\text { spots on the surface with clear } \\
\text { fluid on the inside }\end{array}$ \\
\hline $\begin{array}{c}\text { II } \\
\text { (Immature) }\end{array}$ & $\begin{array}{l}\text { Testes appear larger. The shape } \\
\text { is clearer than stage I, and there } \\
\text { is a dark gray longitudinal line. }\end{array}$ & $\begin{array}{l}\text { The grey spots on the surface are } \\
\text { getting clearer, eggs still not } \\
\text { visible to naked eyes }\end{array}$ \\
\hline $\begin{array}{c}\text { III } \\
\text { (Developing) }\end{array}$ & $\begin{array}{l}\text { The testes surface looks jagged, } \\
\text { the color in the upper part is } \\
\text { yellowish-white, the lower part } \\
\text { is milky white, and there is a } \\
\text { black longitudinal line. }\end{array}$ & $\begin{array}{l}\text { The ovary appears larger. The } \\
\text { ovary surface is gray with black } \\
\text { spots, the oocyte granules are } \\
\text { visible, and there is still a lot of } \\
\text { milky white connective tissue. }\end{array}$ \\
\hline $\begin{array}{c}\text { IV } \\
\text { (Early Ripening) }\end{array}$ & $\begin{array}{l}\text { The testis shape is getting } \\
\text { bigger, jagged, and solid, and } \\
\text { the black longitudinal line is } \\
\text { only found in the anterior part. }\end{array}$ & $\begin{array}{l}\text { The gonad surface is jagged and } \\
\text { black, The oocytes are yellow, } \\
\text { but the dominant oocytes are still } \\
\text { milky white. There is still much } \\
\text { connective tissue, and the } \\
\text { diameter of the oocytes is not } \\
\text { uniform. }\end{array}$ \\
\hline $\begin{array}{c}\mathrm{V} \\
\text { (Ripe) }\end{array}$ & $\begin{array}{l}\text { Wrinkled surface, milky white } \\
\text { color, a less than half TKG IV. }\end{array}$ & $\begin{array}{l}\text { The ovarian surface is black, and } \\
\text { ovarian walls are thin, more than } \\
\text { oocytes is clear yellowish, no } \\
\text { connective tissue is found, } \\
\text { oocyte diameter is larger than } \\
\text { TKG IV }\end{array}$ \\
\hline
\end{tabular}

The length-weight relationship of fish were estimated using equation [26]:

$$
W=a L^{b}
$$

where: $\mathrm{W}=$ weight of fish $(\mathrm{g}) ; \mathrm{L}=$ total length of fish $(\mathrm{mm}), \mathrm{a}=$ intercept or the initial growth index; $\mathrm{b}=$ slope or the growth coefficient or an exponent

The t-test $(p<0.05)$ was applied to determine the value of $b=3$ or not. If the value of $b$ $=3$ means that the fish has an isometric growth pattern, on the contrary, if $b \neq 3$ means the growth pattern is allometric.

Fish condition factor $(\mathrm{K})$ on isometric growth were calculated by formula [27]:

$$
K=10^{5} \mathrm{~W} / \mathrm{L}^{3}
$$

where : $\mathrm{w}=$ body weight $(\mathrm{g}), \mathrm{L}=$ length $(\mathrm{mm})$

In allometric condition, the relative condition factor was calculated using the formula [28]:

$$
K_{n}=W / W^{*}
$$

where: $\mathrm{K}_{\mathrm{n}}=$ condition factor, $\mathrm{W}=$ observed weight $(\mathrm{g}), \mathrm{W}^{*}=$ weight calculated from length-weight relationship 


\section{Result and discussion}

\subsection{Result}

\subsubsection{Length-weight relationship}

A total of 550 fish were captured consisted of 227 fish in the Camba River, 88 fish in the Sanrego River, and 235 fish in the Batu Puteh River. The male range of M. ladigesi in Camba River was 28,8-61,2 mm in length, and 0,2158-1,7335 g in weight, and the female range was 26,7-60,1 $\mathrm{mm}$ in length $0,0992-2,083 \mathrm{~g}$ in weight. The male and female range of M. ladigesi in Sanrego River was 26,5-51,4 $\mathrm{mm}$ and $15,1-51,4 \mathrm{~mm}$ in length respectively and 0,1808-1,1220 g dan 0,0308-1,2669 g in weight respectively. In Batu Puteh River, the male range of $M$. ladigesi River was $23,6-56,2 \mathrm{~mm}$ in length and $0,1082-1,7312 \mathrm{~g}$ in weight, and the female content was 22,6-52,4 mm in length and 0,1152-1,5697 $\mathrm{g}$ in weight.

The length-weight relationship of $M$. ladigesi is shown in Figure 2. The correlation coefficient (r) value of LWR for male and female M. ladigesi were 0.98 and 0.92 in Camba River, 0.97 and 0.98 in Sanrego River, and 0.98 and 0.98 in Batu Puteh River, respectively. Based on the value of the correlation coefficient (r), it was found that the length and weight of $M$. ladigesi have a strong correlation that means increasing fish length affects the increase in body weight of the fish.

The analysis length-weight relationship of $M$. ladigesi was carried out separately between male and female individuals. The result of length-weight relationship analysis obtained the relationship models and growth patterns of fish, as shown in Table 2.

The equation of length-weight relationships and the growth pattern of $M$. ladigesi varies based on the same sex and different sexes. In Table 1, the regression coefficient value (b) for the male fish is 2.74, and the female fish is 3.23 in Camba River. The regression coefficient value (b) in Sanrego and Batu Puteh Rivers were 2.78 and 2.88 for males and 2.92 and 3.12 for females, respectively.

Table 2. Length-weight relationship and growth type of $M$. ladigesi in rivers of the Walanae Cenranae Watershed from April 2018 to May 2019

\begin{tabular}{|c|c|c|c|c|c|c|}
\hline Location & Sex & $\mathbf{n}$ & $\begin{array}{c}\text { Length-weight } \\
\text { relationship }\end{array}$ & $\mathbf{r}$ & $\begin{array}{c}\text { Growth } \\
\text { type }\end{array}$ & T-test \\
\hline \multirow{2}{*}{ Camba River } & Male & 54 & $\mathrm{~W}=0,0002 \mathrm{~L}^{2,74}$ & 0,98 & NA & $\mathrm{t}_{\text {-count }}>\mathrm{t}_{\text {-table }}$ \\
\hline & Female & 173 & $\mathrm{~W}=0,00004 \mathrm{~L}^{3,23}$ & 0,92 & PA & $\mathrm{t}_{\text {-count }}>\mathrm{t}$-table \\
\hline \multirow{2}{*}{ Sanrego River } & Male & 33 & $\mathrm{~W}=0,0001 \mathrm{~L}^{2,78}$ & 0,97 & I & $\mathrm{t}_{\text {-count }}<\mathrm{t}_{\text {-table }}$ \\
\hline & Female & 55 & $\mathrm{~W}=0,0001 \mathrm{~L}^{2,92}$ & 0,98 & I & $\mathrm{t}_{\text {-count }}<\mathrm{t}_{\text {-table }}$ \\
\hline \multirow{2}{*}{$\begin{array}{l}\text { Batu Puteh } \\
\text { River }\end{array}$} & Male & 112 & $\mathrm{~W}=0,0001 \mathrm{~L}^{2,88}$ & 0,98 & NA & $t_{\text {-count }}>t_{\text {-table }}$ \\
\hline & Female & 123 & $\mathrm{~W}=0,00006 \mathrm{~L}^{3,12}$ & 0,98 & NA & $\mathrm{t}_{\text {-count }}>\mathrm{t}_{\text {-table }}$ \\
\hline
\end{tabular}

Descriptions: n: total individual, r: correlation coefficient, NA: negative allometric, PA: positive allometric, I: isometric 

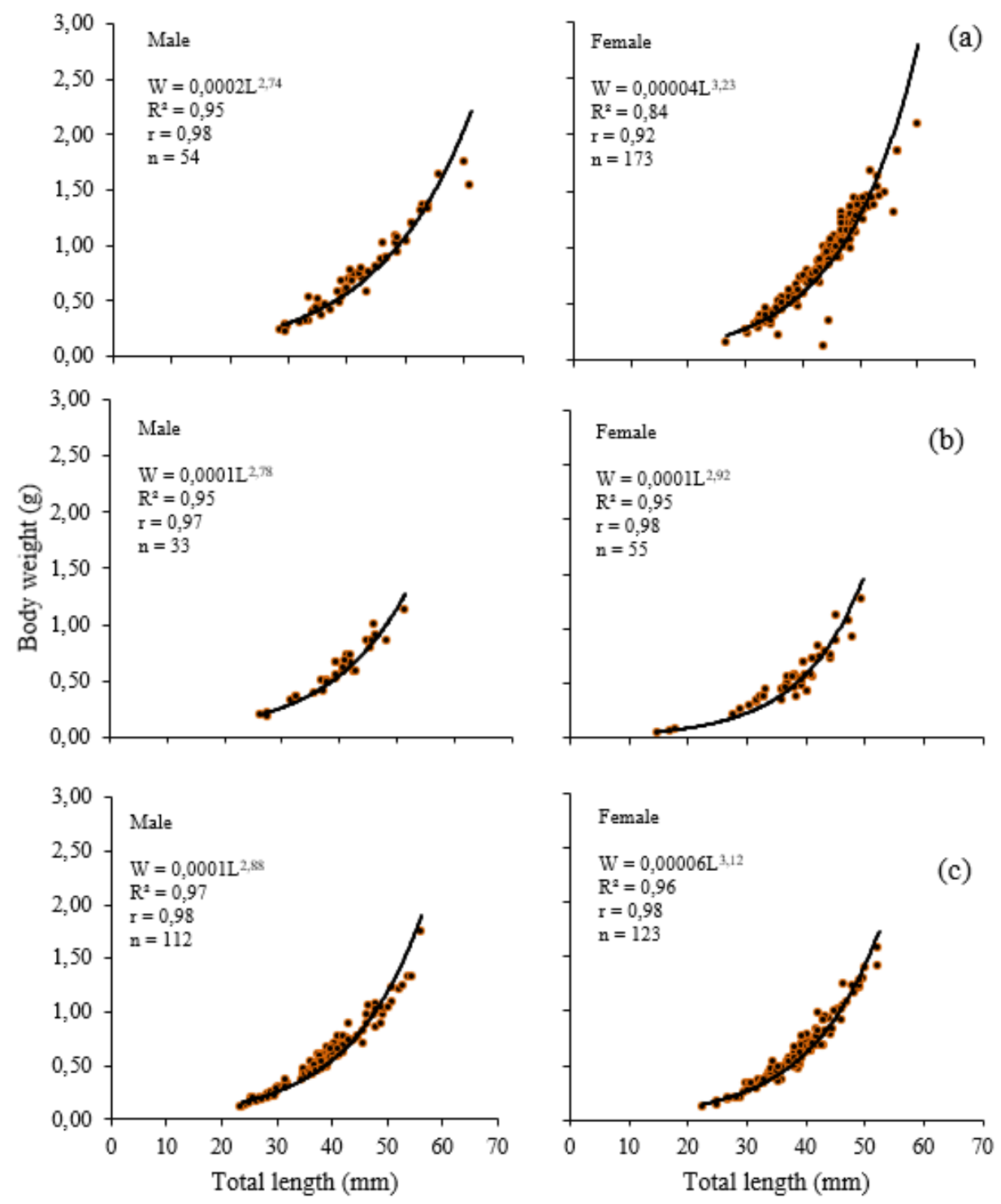

Fig. 2. Length-weight relationships of M. ladigesi from May 2018 to April 2019 (a) Camba River (b) Sanrego River (c) Batu Puteh River

\subsubsection{Condition factors}

The value of condition factor based on gonad maturity varied, but the value increased as the gonad maturity increased (Table 3-5). The average condition factor value of male and female M. ladigesi in Camba, Sanrego, and Batu Puteh Rivers (Table 6) were 0,728-1,012 dan 0,921-1,069, 0,795-0,987 dan 0,786-1,196, dan 0,868-0,994 dan 0,903-1,077, respectively. The average condition factor for male and female M. ladigesi from May 2018 to April 2019 in Camba, Sanrego, and Batu Puteh Rivers is shown in Figure 3 that female fish have a higher condition factor value than male fish. 
Table 3. Condition factor of M. ladigesi based on gonad maturity from May 2018 to April 2019 in Camba River

\begin{tabular}{|c|c|c|c|c|c|c|c|c|}
\hline \multirow{2}{*}{$\begin{array}{c}\text { Gonad } \\
\text { maturity }\end{array}$} & \multicolumn{5}{|c|}{ Male } & \multicolumn{5}{c|}{ Female } \\
\cline { 2 - 9 } & Range & Average & $\mathrm{Sd}$ & $\mathrm{n}$ & Range & Average & $\mathrm{Sd}$ & $\mathrm{n}$ \\
\hline I & $0.827-1.166$ & 0.972 & 0.107 & 8 & $0.457-1.044$ & 0.870 & 0.161 & 13 \\
\hline II & $0.714-1.102$ & 0.953 & 0.105 & 13 & $0.755-1.177$ & 0.985 & 0.103 & 30 \\
\hline III & $0.794-1.410$ & 0.942 & 0.189 & 9 & $0.731-1.207$ & 1.018 & 0.116 & 19 \\
\hline IV & $0.791-1.122$ & 0.907 & 0.078 & 19 & $0.117-1.231$ & 1.023 & 0.134 & 70 \\
\hline V & $0.666-1.013$ & 0.871 & 0.136 & 5 & $0.378-1.184$ & 0.990 & 0.122 & 41 \\
\hline
\end{tabular}

$\mathrm{Sd}=$ standard deviation

Table 4. Condition factor of M. ladigesi based on gonad maturity from May 2018 to April 2019 in Sanrego River

\begin{tabular}{|c|c|c|c|c|c|c|c|c|}
\hline \multirow{2}{*}{$\begin{array}{c}\text { Gonad } \\
\text { maturity }\end{array}$} & \multicolumn{4}{|c|}{ Male } & \multicolumn{5}{c|}{ Female } \\
\cline { 2 - 9 } & Range & Average & $\mathrm{Sd}$ & $\mathrm{N}$ & Range & Average & $\mathrm{Sd}$ & $\mathrm{n}$ \\
\hline I & $0.851-1.030$ & 0.950 & 0.075 & 4 & $0.890-1.044$ & 0.965 & 0.059 & 7 \\
\hline II & $0.839-0.958$ & 0.918 & 0.069 & 3 & $0.618-1.182$ & 0.937 & 0.185 & 12 \\
\hline III & $0.831-1.058$ & 0.935 & 0.097 & 8 & $0.785-1.103$ & 0.941 & 0.108 & 7 \\
\hline IV & $0.722-0.954$ & 0.834 & 0.084 & 14 & $0.620-1.003$ & 0.854 & 0.117 & 13 \\
\hline V & $0.826-1.023$ & 0.930 & 0.084 & 4 & $0.846-1.196$ & 0.981 & 0.094 & 16 \\
\hline
\end{tabular}

$\mathrm{Sd}=$ standard deviation

Table 5. Condition factor of M. ladigesi based on gonad maturity from May 2018 to April 2019 in Batu Puteh River

\begin{tabular}{|c|c|c|c|c|c|c|c|c|}
\hline \multirow{2}{*}{$\begin{array}{c}\text { Gonad } \\
\text { maturity }\end{array}$} & \multicolumn{5}{|c|}{ Male } & \multicolumn{5}{c|}{ Female } \\
\cline { 2 - 9 } & Range & Average & $\mathrm{Sd}$ & $\mathrm{n}$ & Range & Average & $\mathrm{Sd}$ & $\mathrm{N}$ \\
\hline I & $0.813-1.200$ & 0.938 & 0.101 & 20 & $0.736-1.180$ & 0.934 & 0.112 & 26 \\
\hline II & $0.833-1.097$ & 0.942 & 0.084 & 19 & $0.868-1.269$ & 1.030 & 0.102 & 19 \\
\hline III & $0.783-1.105$ & 0.914 & 0.079 & 32 & $0.836-1.095$ & 0.971 & 0.067 & 18 \\
\hline IV & $0.727-1.102$ & 0.913 & 0.106 & 30 & $0.826-1.291$ & 1.010 & 0.095 & 44 \\
\hline V & $0.810-0.999$ & 0.901 & 0.072 & 11 & $0.903-1.232$ & 1.026 & 0.094 & 16 \\
\hline
\end{tabular}

$\mathrm{Sd}=$ standard deviation 
Table 6. Condition factor of M. ladigesi from May 2018 to April 2019 in Camba, Sanrego, and Batu Puteh Rivers

\begin{tabular}{|c|c|c|c|c|c|c|}
\hline \multirow{2}{*}{ Location } & \multicolumn{3}{|c|}{ Male } & \multicolumn{3}{c|}{ Female } \\
\cline { 2 - 7 } & Range & Average \pm SE & $\mathrm{n}$ & Range & Average \pm SE & $\mathrm{n}$ \\
\hline Camba River & $0,728-1,012$ & $0,908 \pm 0,088$ & 54 & $0,921-1,069$ & $1,002 \pm 0,052$ & 173 \\
\hline Sanrego River & $0,795-0,987$ & $0,885 \pm 0,071$ & 33 & $0,786-1,196$ & $0,956 \pm 0,130$ & 55 \\
\hline Batu Puteh River & $0,868-0,994$ & $0,920 \pm 0,043$ & 112 & $0,903-1,077$ & $0,993 \pm 0,054$ & 123 \\
\hline
\end{tabular}

Description: $\mathrm{n}$ : total individual, SE: standard error

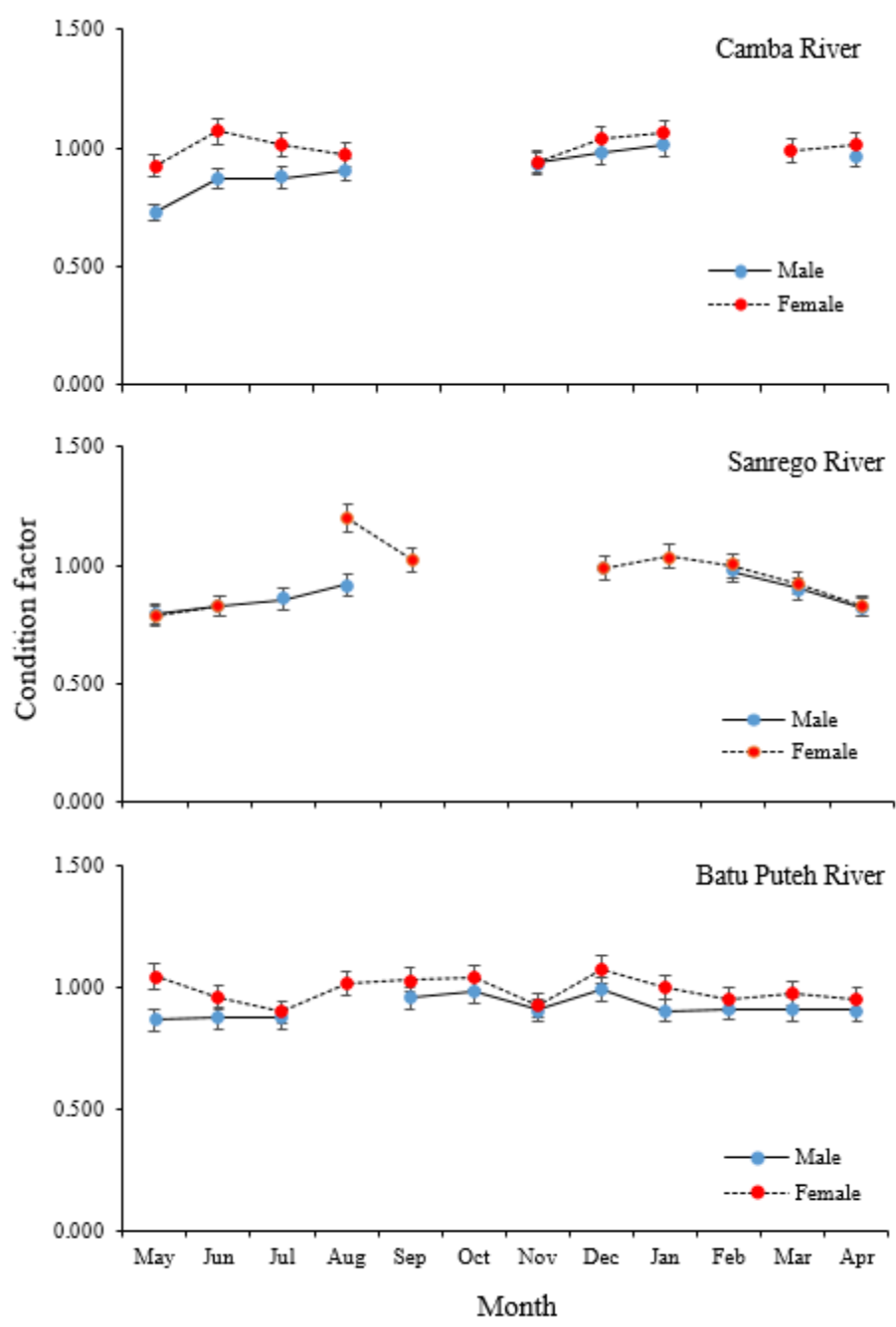

Fig. 3. Condition factor of M. ladigesi both male and female from May 2018 to April 2019 in Camba, Sanrego, and Batu Puteh Rivers 


\subsection{Discussion}

The limit information study of $M$. ladigesi is the length-weight relationship that determines the growth pattern of $M$. ladigesi in South Sulawesi Waters. Meanwhile, this study is requisite for the management and conservation of fish populations, as well as a tool to evaluate fish life history [28], fish growth patterns [29], and assessing fisheries biomass [30].

The equation of the LWR model is shown in Table 1. The growth pattern of male fish in the Camba River and Batu Puteh River shows a negative allometric growth pattern, which means the length increased proportionately faster than body weight. In contrast, the growth pattern of female fish is positive allometric, which means the body weight increased proportionately faster than length during growth. The growth pattern of allometric male fish is negatively related to the behavior of male fish, who are more active and have a large movement area because of their slender body shape. The growth pattern of allometric female fish is positively related to the maturation of the gonads and the passive behavior of the female fish. Hence their energy is allocated for movement and growth. [31] added that riverbank areas with low water flow have more food sources, and the passive behavior of female fish who are more in the riverbank area will get more and varied food supply than male fish who are more active. In contrast, the growth patterns of male and female fish in the Sanrego River are isometric. Differences in male and female fish growth patterns are influenced by gonad maturation [32], sex, season, habitat [33, 34, 35, 36], and environmental conditions and biology [37].

The study of condition factors is essential because it shows indicators of the physiological state of fish in terms of their physical ability to survive and reproduce [38] and evaluation characteristics of the populations and biomass [39]. Based on gonad maturity (Table 3-5), the value of the condition factor for each gonad maturity varied. Male and female fish had condition factors that decreased with increasing gonadal maturity to TKG III, then condition factors increased at TKG IV and dropped again after fish spawned. This happens because the largest part of the food consumed develops reproductive cells [40]. The same thing was also found in the research of [41] and [42], which stated that the increasing condition factor corresponds to the increase in gonad maturity.

The average condition factors in the three rivers during the study can be seen in Table 5 and Figure 3. The highest condition factor for the condition of beseng-beseng was found in the Camba River, namely male fish 0.908 and female fish 1.002 and in Batu Puteh River the range of condition factors for male and female fish. are 0.920 and 0.993 , respectively. The lowest condition factor values in the Sanrego River were male fish 0.885 and female fish 0.956. The high value of the condition factor for male and female fish in the Camba River and Batu Puteh River is thought to be influenced by the availability of food in the two rivers, which are more diverse due to unspoiled riparian conditions, especially in the Batu Puteh River which provides a food source. This study found that the condition factor for female fish was greater than male fish. These results indicate a better condition for the female fish to adapt and survive for the reproductive process.

\section{Conclusion}

In the Camba and Batu Puteh Rivers, the growth pattern of M. ladigesi was a negative allometric in males and positive allometric in females. Conversely, the growth patterns of male and female fish in the Sanrego River were isometric. The condition factor of fish in the Sanrego River was lower than Camba and Batu Puteh Rivers. The condition factor for female fish was more significant than male fish. 


\section{References}

1 A. J. Whitten, K. D. Bishop, S. V. Nash, L. Clayton, Conserv. Biol. 1, 7 (1987)

2 M. Kottelat, A. J. Whitten, S. N. Kartikasari, S. Wirjoatmo, Freshwater Fishes of Western Indonesia and Sulawesi (PEP EMDI, Jakarta, 1993)

3 L. R. Parenti, SNI 610 (2011)

4 F. W. Miesen, F. Droppelmann, S. Hullen, R. K. Hadiaty, F. Herder, Bonn. Zool. Bull. 64, 2 (2016)

5 R. K. Hadiaty, J. Iktiologi Indones. 18, 2 (2018)

6 I. F. Mandagi, D. F. Mokodongan, R. Tanaka, K. Yamahira, Copeia. 106, 2 (2018)

7 J. Kraemer, R. K. Hadiaty, F. Herder, Ichthyol. Explor. Freshw. 1105, 8 (2019)

8 H. Kobayashi, K. W. A. Masengi KWA, Yamahira K, Copeia. 108, 3 (2020)

9 P. Keith, E. Delrieu-trottin, L. V. Utama, S. Sauri, F. Busson, Nurjirana, D. Wowor, D. Dahruddin, N. Hubert, Cybium., 451 (2021)

10 I. Andriani, Postgraduate, Bogor (ID): IPB University, (2000)

11 D. S. Said, Warta Iktiologi 1, 2 (2017)

12 Aarn, W. Ivanstsoff, M. Kottelat, Ichthyol. Explor. Freshw. 9, 12 (1998)

13 Jayadi, A. Tamsil, S. T. Hadijah, MKL 6 (2015)

14 S. H. Nasution, D. S. Said, Lukman, Triyanto, H. Fauzi, SNI 410 (2006)

15 Kariyanti, S. B. A. Omar, J. Tresnati, Simnaskp 11 (2014)

16 S. Bin. Andy Omar, Kariyanti, J. Tresnati, M. T. Umar MT, Kune, Semnaskan, 6 (2014).

17 Jayadi, St. Hadijah, B. Tang, A. Husma, J Iktiologi Indones 16, 13 (2016)

18 A. F. A. Nasyrah, M. F. Rahardjo, C. P. H. Simanjuntak, J. Iktiologi Indones. 20, 17 (2020)

19 D. S. Said, N. Mayangsari, Indones. Aquac. J. 8, 6 (2007)

20 Triyanto, S. D. Said, J. Iktiologi Indones. 6, 7 (2006)

21 R. K. Hadiaty, Ber. Biol., 86 (2007)

22 Jayadi, A. Husma, Nursahran, Ardiansyah, Sriwahidah, Aquac. Aquar. Conserv. Legis. 9, 10 (2016)

23 D. S. Said, Warta Iktiologi 1, 6 (2017)

24 Jayadi, S. Hadijah, Harlina, Rustam, Nursahran, Pak. J. Biol. Sci. 21, 8 (2018)

25 S. B. A. Omar, Kariyanti, D. Yanuarita, M. T. Umar, Y. S. A. Lawi, Aquac. Aquar. Conserv. Legis. 13, 12 (2020)

26 M. I. Effendie, Fisheries Biology Method (YDS, Bogor, 1979)

27 W. E. Ricker, Computation and interpretation of biological statistics of fish population (BFRB of Canada, Ottawa, 1975)

28 J. Oscoz, F. Campos, M. C. Escala, J. Appl. Ichthyol. 21, 1 (2005)

29 N. Jisr, G. Younes, C. Sukhn, M. H. El-Dakdouki, Egypt J. Aquat. Res. 44, 6 (2018)

30 X. Cai, G. Li, F. Li, H. Wang, Y. Zhang, D. Gu, Z. Shen, J. Appl. Ichthyol., 352 (2019)

31 E. Manangkalangi, M. F. Rahardjo, D. S. Sjafei, Sulistiono, J. Iktiologi Indones., 10 12 (2010) 
32 A. S. Batubara, Z. A. Muchlisin, D. Efizon, R. Elvyra, M. Irham, Vestn. Zool., 53, 7 (2019)

33 G. Moradinasab, M. Daliri, R. Ghorbani, S. Y. Paighambari, R. Davoodi, Casp. J. Environ. Sci. 10, 6 (2012)

34 M. A. Hamid, M. Mansor, S. A. M. Nor, Sains Malays. 44, 5 (2015)

35 M. Moeslen, R. K. Daka, J. Aqua. Fisheries Manage. 1, 4 (2017)

36 Djumanto, A. Murjiyanti, N. Azlina, A. Nurulitaerka, A. Dwiramdhani, J. Iktiologi Indones. 19, 15 (2019)

37 M. Nur, M. F. Rahardjo, C. P. H. Simanjuntak, Djumanto, Krismono, J. Iktiologi Indones. 20, 8 (2020)

38 M. M. Alam, M. T. Rahman, S. Parween, Int. J. Aquat. Biol. 2, 5 (2014)

39 R.S Da Silva, L. R. Virgilio, F. Corrêa, L. J. S. Vieira, J. Appl. Ichthyol. 36, 2 (2020)

40 M. F. Rahardjo, C. P. H. Simanjuntak, J. Ilmu-Ilmu Perair. dan Perikan. Indones. 15, 6 (2008)

41 A. Zahid, C. P. H. Simanjuntak, J. Iktiologi Indones. 9, 10 (2009)

42 M. T. Gundo, M. F. Rahardjo, D. T. F Lumban Batu, W. Hadie, J. Iktiologi Indones. 14, 9 (2014) 